\title{
Bacterial community structure along the Adour estuary (French Atlantic coast): influence of salinity gradient versus metal contamination
}

\author{
M. S. Goñi-Urriza ${ }^{1, *}$, D. Point ${ }^{2}$, D. Amouroux ${ }^{2}$, R. Guyoneaud ${ }^{1}$, O. F. X. Donard ${ }^{2}$, \\ P. Caumette ${ }^{1}$, R. Duran ${ }^{1}$ \\ ${ }^{1}$ Equipe Microbiologie et Environnement, IPREM, UMR CNRS 5254, Bâtiment IBEAS, Université de Pau et des Pays de l'Adour, \\ BP1155, 64013 Pau, France \\ ${ }^{2}$ Equipe Chimie Analytique Bio-Inorganique et Environnement, IPREM, UMR CNRS 5254, \\ Université de Pau et des Pays de l'Adour, 64053 Pau, France
}

\begin{abstract}
Salinity, other physico-chemical parameters and anthropogenic pollution are the main factors affecting bacterial communities in estuaries. We estimated the impact of these parameters on the distribution of bacterial communities in the Adour estuary (France), a moderately polluted water body characterized by short residence times of particles and water and absence of a maximum turbidity zone. Eight stations were established along the salinity gradient from freshwater to marine conditions. For the 3 typical estuarine stations (water mixing zone), samples were collected at both low and high tide and at different depths according to the position of the halocline. This sampling strategy generated 35 samples with different degrees of mixing between fresh water and seawater. All the samples were characterized by their physico-chemical parameters and trace metal contents (as a contamination tracer). The structure of bacterial communities was determined by T-RFLP fingerprinting. The metal-salinity profiles suggested dilution processes and/or usual geochemical reactivity for the elements sensitive to sorption/desorption mechanisms ( $\mathrm{Cd}, \mathrm{Mn})$. Metal concentrations were low, with no evidence of contaminated plumes, suggesting that metal concentrations were not influencing bacterial diversity. A well-established estuarine bacterial community was observed, comprising mostly Cyanobacteria, Planctomyces and Alphaproteobacteria. This community was different from fresh and seawater communities, and a shift in community composition was observed between 10 and 34 PSU. Although residence time in the Adour estuary is very short, the salinity and halocline in this water body are likely to be the main parameters influencing bacterial community composition.
\end{abstract}

KEY WORDS: Bacterial communities $\cdot$ Salinity gradient $\cdot$ Heavy metals $\cdot$ Estuary $\cdot$ Halocline $\cdot$ T-RFLP

Resale or republication not permitted without written consent of the publisher

\section{INTRODUCTION}

Bacterial communities in estuarine ecosystems are exposed to strong changes in environmental conditions. The mixing of seawater and freshwater, the variations in residence time, the transportation of either dissolved or suspended organic and inorganic material, as well as modifications due to climatic conditions may induce specific patterns of bacterial abundance, diversity and activity in these ecosystems. Differences in bacterial abundances have been demonstrated along the salinity gradients in the Rhone estuary and the Columbia River (Crump et al. 1999, Troussellier et al. 2002). The sharp phylogenetic succession that occurs in fresh to saltwater transition regions is accompanied by profound physiological changes at the community level (del Giorgio \& Bouvier, 2002). However, available data on bacterial diversity have led to inconsistent conclusions. Some studies have demonstrated how freshwater and marine bacterioplankton communities mix along estuarine gradients, concluding that bacterioplankton in the estuarine zone appears to be 
a mixture of both communities (Trousellier et al. 2002, Kirchman et al. 2005, Zhang et al. 2006). Nevertheless, few reports have provided evidence for a unique estuarine bacterial community in the brackish part of these ecosystems (Crump et al. 1999, 2004, Hollibaugh et al. 2000, Selje \& Simon 2003). Whatever their conclusions, all these studies strongly suggest that the residence times of particles and particle-attached bacteria in estuarine turbidity maxima (ETM) are likely main factors influencing the development of a unique estuarine bacterial community. In addition, Hewson \& Fuhrman (2004) concluded that nutrient gradients that are frequently found in these environments could influence the richness and diversity of estuarine bacterioplankton. On the other hand, Kirchman et al. (2005) reported that the main factor influencing the abundance of different bacterial groups was salinity. However, these authors did not identify a distinct estuarine bacterial community.

In recent years, whole-community molecular fingerprinting approaches have been extensively used to study in situ bacterial diversity. All these molecular methods are rather time consuming and costly, and they lead to a variety of phylogenetic and taxonomic resolutions. Most of the studies cited above used high resolution techniques such as DGGE or clone libraries, with consequently small sample sizes. Others used FISH techniques leading to a lower resolution but also to an ability to process many more samples. In this study, we used terminal restriction fragment length polymorphism (T-RFLP), which provides good resolution in the spatial distribution of bacterial communities while allowing the analysis of large number of samples.

The occurrence of a unique estuarine bacterial community is a controversial topic (Crump et al. 1999, Hollibaugh et al. 2000, Trousellier et al. 2002, Selje \& Simon 2003, Kirchman et al. 2005, Zhang et al. 2006). The Adour estuary (southwestern French Atlantic coast) has a moderate pollution level, short water residence time (Point 2004, Point et al. 2006), efficient water mixing, low ETM and a well defined halocline (De Casamajor 1995). In addition, the downstream section of the Adour estuary has an important urban and industrial area (Bayonne city district) that may contribute significant anthropogenic inputs to estuarine waters, e.g. metallic contaminants (Point 2004, Stoichev et al. 2006). This combination of conditions is well suited for a study of estuarine bacterial community structure. We analyzed the bacterial communities along the salinity gradient at both low and high tide to determine the effects of environmental parameters, such as the halocline and other physical and chemical factors (e.g. $\mathrm{O}_{2}$ concentrations, $\mathrm{pH}$, POC, SPM) on the establishment of a putative typical estuarine bacterial community. Heavy metal content in these waters was also determined to investigate the impact of anthropogenic inputs over natural environmental gradients.

\section{MATERIALS AND METHODS}

Area of investigation and sampling strategies. The Adour estuary is located in southwestern France and flows into the Bay of Biscay (Atlantic Ocean). The region under investigation (Fig. 1), located between KP150 and KP120, was defined by the marine water tidal intrusion limit (KP120) and the estuarine turbidity plume limit (KP148). The upstream part of this sampling area is surrounded by extensive agricultural areas. Direct anthropogenic pressure by sewage effluents and industrial activities (mainly iron and steel industries) occur downstream at the estuarine mouth and in the vicinity of the city of Bayonne (KP 120 and 135).

A total of 8 stations (Fig. 1) were sampled along an estuarine-coastal transect on 14 to 16 June 2001 using the research vessel 'Côte de la Manche' (CNRS/INSU). The average river discharge entering the estuary was $185 \mathrm{~m}^{3} \mathrm{~s}^{-1}$, slightly lower than the annual average $\left(255 \mathrm{~m}^{3} \mathrm{~s}^{-1}\right)$. Vertical profiles of salinity, temperature and conductivity (using a CTD probe, Seabird SBE-25) were measured for all stations in order to determine

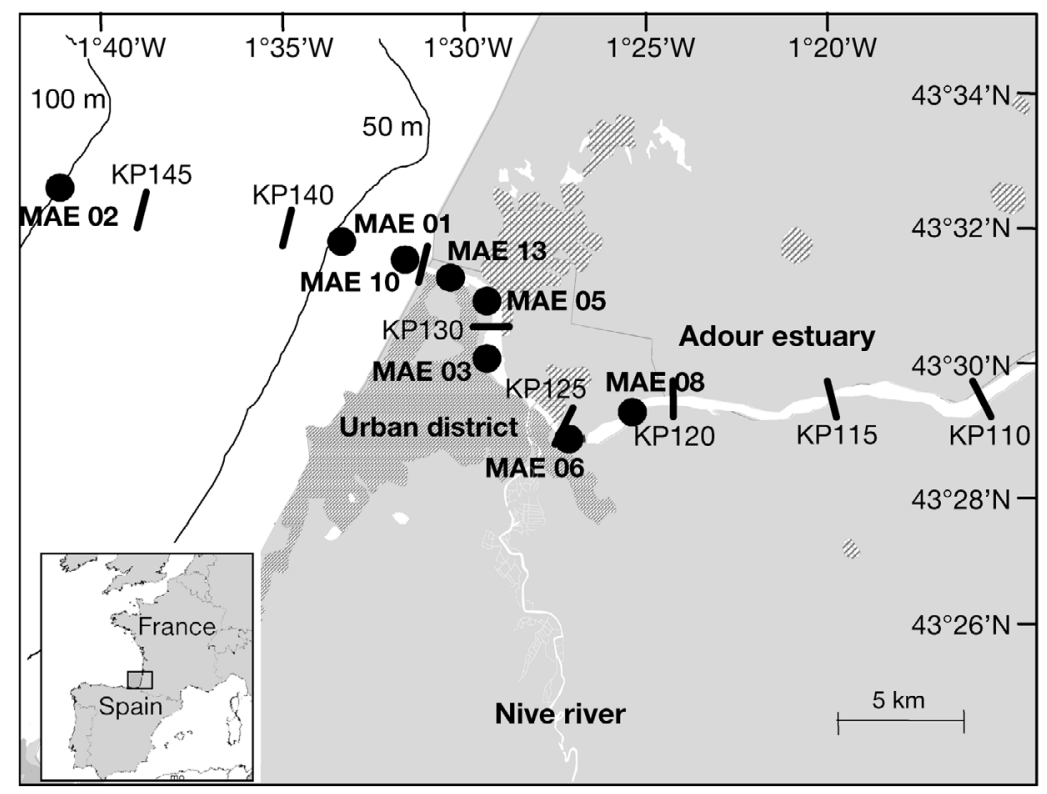

Fig. 1. The Adour estuary with sampling sites (labelled with prefix MAE). KP: kilometric point 
the appropriate sampling depths. The seawater stations (MAE 01, MAE 02 and MAE 10) were sampled at different depths only once because there was no difference in stratification between high and low tides. Two freshwater stations (MAE 06 and MAE 08) were also sampled only once and at the sub-surface due to their shallowness. The other 3 stations (MAE 03, MAE 05 and MAE 13), located in the estuary channel, were sampled twice (at low and high tide) at different depths, depending on the halocline position (see Table 1 for details). All samples were identified by station number (see Fig. 1), tide conditions when applicable, and depth of sampling (Table 1).

Table 1. Sample codes (see Fig. 1 for locations) and summarized descriptions of all samples analyzed. Sample codes include sampling station number (MAE01-MAE13, see Fig. 1), tidal conditions when applicable $(\mathrm{H}$, high tide; $\mathrm{L}$, low tide) and depth of sample (m), in sequence. Symbol: samples are classified into 5 groups: 0 : seawaters; O: estuarine waters with salinity $>24 \mathrm{~g} \mathrm{l}^{-1}$; $\square$ : estuarine waters with salinity between 11 and $24 \mathrm{~g} \mathrm{l}^{-1} ; \Delta$ : estuarine waters with salinity under $11 \mathrm{~g} \mathrm{l}^{-1}$; and $\boldsymbol{\Delta}$ : fresh water. KP: kilometric point; ND: not done. The symbols are used in Figs. 2, 3, 4 \& 5

\begin{tabular}{|c|c|c|c|c|}
\hline Sample & $\begin{array}{c}\mathrm{KP} \\
(\mathrm{km})\end{array}$ & $\begin{array}{c}\text { Temperature } \\
\left({ }^{\circ} \mathrm{C}\right)\end{array}$ & $\begin{array}{l}\text { Salinity } \\
\text { (PSU) }\end{array}$ & Symbol \\
\hline MAE 0202 & 147 & 21.4 & 33.4 & ○ \\
\hline MAE 0205 & 147 & 21.6 & 33.4 & 0 \\
\hline MAE 0210 & 147 & 21.1 & 33.6 & 0 \\
\hline MAE 0220 & 147 & 21.1 & 34.2 & 0 \\
\hline MAE 0245 & 147 & 16.4 & 34.3 & 0 \\
\hline MAE 0290 & 147 & 19.7 & 34.8 & 0 \\
\hline MAE 0102 & 140 & 21.5 & 30.1 & 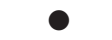 \\
\hline MAE 0104 & 140 & 21.3 & 31.4 & 0 \\
\hline MAE 0110 & 140 & 21.1 & 33.6 & ○ \\
\hline MAE 0125 & 140 & 21.5 & 34.6 & ○ \\
\hline MAE 0145 & 140 & 21.7 & 34.8 & ○ \\
\hline MAE 1001 & 137 & 21.1 & 31.7 & O \\
\hline MAE 1003 & 137 & 21.3 & 32.9 & 0 \\
\hline MAE 1010 & 137 & 21.3 & 33.3 & 0 \\
\hline MAE 1025 & 137 & 20.3 & 33.6 & 0 \\
\hline MAE 13L 01 & 135 & 19.7 & 20.6 & $\square$ \\
\hline MAE 13L 03 & 135 & 19.7 & 23.8 & $\mathbf{\square}$ \\
\hline MAE 13L 10 & 135 & 20.2 & 32.7 & 0 \\
\hline MAE $13 \mathrm{H} 01$ & 135 & 20.5 & 33.1 & 0 \\
\hline MAE $13 \mathrm{H} 03$ & 135 & 22.6 & 33.3 & 0 \\
\hline MAE $13 \mathrm{H} 12$ & 135 & 21.5 & 33.4 & 0 \\
\hline MAE 03L 01 & 129.7 & 20.7 & 2.7 & $\triangle$ \\
\hline MAE 03L 04 & 129.7 & 20.9 & 4 & $\Delta$ \\
\hline MAE 03L 07 & 129.7 & 19.1 & 11.3 & $\Delta$ \\
\hline MAE 03Н 01 & 129.7 & 21 & 10.8 & $\Delta$ \\
\hline MAE 03Н 03 & 129.7 & 23.5 & 20.1 & $\mathbf{\square}$ \\
\hline MAE 03H 07 & 129.7 & 23.5 & 29.6 & 0 \\
\hline MAE 05L 01 & 131.5 & 22.4 & 3.8 & $\triangle$ \\
\hline MAE 05L 05 & 131.5 & 21.1 & 9.8 & $\bar{\Delta}$ \\
\hline MAE 05L 10 & 131.5 & 20.5 & 18.5 & $\bar{\square}$ \\
\hline MAE $05 \mathrm{H} 01$ & 131.5 & 21 & 13.1 & ND \\
\hline MAE 05H 03 & 131.5 & 20.2 & 23.2 & 口 \\
\hline MAE 05H 10 & 131.5 & 20.9 & 31.3 & O \\
\hline MAE 060.5 & 121.5 & 19.7 & 0.1 & $\Delta$ \\
\hline MAE 080.5 & 119 & 18.8 & 0.1 & $\Delta$ \\
\hline
\end{tabular}

Main physico-chemical parameters. Factors such as temperature, conductivity, $\mathrm{pH}$ and oxygen were measured both in the field and in the laboratory using a manual instrument (WTW Instruments). The determination of suspended particulate matter (SPM) was performed by filtration onto dry pre-weighed filters (Whatmann GF/F, $0.7 \mu \mathrm{m})$. Particulate organic carbon was determined (according to Point et al. 2007) as a percentage of dried SPM

For silicate analysis, samples were treated according to Strickland \& Parsons (1972), and determinations were made on a Technicon Autoanalyser II according to Tréguer \& Le Corre (1975).

Trace metal determination. All water samples were filtered within $1 \mathrm{~h}$ of collection under a class 100 portable laminar flow hood (ADS Laminaire) using $500 \mathrm{ml}$ polysulfone filtering units (Sartorius) fitted with $0.45 \mu \mathrm{m}$ acid cleaned Durapore PVDF filters (47 mm diameter, Millipore). For trace metals, the dissolved fractions were collected in $125 \mathrm{ml}$ (LDPE) Nalgene bottles and stabilized with $1 \%$ subboiling $\mathrm{HNO}_{3}$ (J.T Baker, Ultrex) The samples were then stored in double Ziploc ${ }^{\mathrm{TM}}$ plastic bags at $4^{\circ} \mathrm{C}$. Blanks were prepared using the same protocol with 18.2 M $\Omega$ MQ water (Millipore). Trace metal determinations in estuarine and marine waters were performed by ICP-MS (Thermo Elemental X7). Beforehand, all samples were UV photolysed and preconcentrated in the field using a dedicated automated platform fitted with Metpac CC1 chelating resins (Dionex). A more detailed description of this procedure is available in Point (2004). The method's accuracy was checked using seawater certified reference material (CASS-4, NRC, Canada).

Bacterial community characterization. Water samples were taken from Niskin bottles and bacteria were concentrated by filtration onto sterile cellulose acetate filters (Millipore, porosity $0.22 \mu \mathrm{m})$. After filtration, the filters were immediately frozen in liquid nitrogen. Filtration volumes varied from 300 to $1000 \mathrm{ml}$, depending on the water turbidity. DNA was extracted from these filters with the UltraClean Soil DNA Isolation Kit using the alternative lysis method (MoBio Laborato- 
ries). All extracted genomic DNA samples were stored at $-20^{\circ} \mathrm{C}$ until further processing.

The primers used for T-RFLP analysis of bacterial community structure were 8F and 926R (Lane 1991, Weisburg et al. 1991) fluorescently labelled with TET (5-Tetrachloro-fluorescein) and HEX (5-Hexa-chlorofluorescein) (E.S.G.S. Cybergene), respectively. PCR amplification was performed as described by Fourçans et al. (2004). PCR products were purified with the GFX PCR DNA purification kit (Amersham).

Purified PCR products (600 to $700 \mathrm{ng}$ ) were digested with 10 units of restriction enzyme HaeIII (New England Biolabs). The lengths of T-RFs from the digested PCR products were determined by capillary electrophoresis (ABI prism 310, Applied Biosystems). About $50 \mathrm{ng}$ of the digested DNA from each sample was mixed with $10 \mu \mathrm{l}$ of deionized formamide and $0.25 \mu \mathrm{l}$ of TAMRA500 size standard (Applied Biosystems) and then denatured at $94^{\circ} \mathrm{C}$ for 2 min and immediately chilled on ice prior to electrophoresis. After an injection step of $10 \mathrm{~s}$, electrophoresis was run for up to $30 \mathrm{~min}$, applying a voltage of $15 \mathrm{KV}$. T-RFLP profiles were analyzed using GeneScan software (Applied Biosystems).

Dominant T-RFs were selected by comparing numerical values and electropherograms. For analysis, only the T-RFs representing more than $1 \%$ of the total fluorescence were considered (Hewson \& Fuhrman 2004). T-RFLP profiles were compared by Principal Component Analysis (PCA) using MVSP v3.13d software (Rockware). Putative identifications of selected T-RFs were performed by in silico restriction of the data using the TAP-TRFLP data base of RDP (Ribosomal Database Project, available at http://rdp.cme.msu.edu). In silico restriction was carried out with HaeIII enzyme for both extremities of the amplification. Each T-RF could generally be associated with 1 phylum. When more than 1 phylum was associated, all phyla were considered for analysis.

\section{RESULTS}

\section{Main physical and chemical parameters}

Total salinity varied from 0.1 to 34.8 PSU (Table 1) and, in some cases, was decisive for the sampling strategy. In order to characterize the halocline, vertical salinity profiles were determined at all stations at both high and low tide. A halocline was detected at estuarine Stns MAE 05 and MAE 03 at high tide (between 1 to $3 \mathrm{~m}$ and 2 to $4 \mathrm{~m}$ depth, respectively), with salinity increasing from 13 to 31 PSU (MAE 05) and from 10 to 29 PSU (MAE 03). A halocline was also found in the mouth of the estuary (Stn MAE 13) at low tide, between 2 and $6 \mathrm{~m}$ depth (salinity increasing from 21 to $31 \mathrm{PSU})$.

The Adour estuary is a typical mixing area between fresh and marine waters as shown by silicate dilution along the salinity gradient (Fig. 2).Turbidity in the estuary was very low; indeed, maximum turbidity was found in the freshwater samples (suspended particular matter SPM $=21.4$ to $24.9 \mathrm{mg} \mathrm{l}^{-1}$, Fig. 2). In the mixing zone, no significant ETM was identified (Fig. 2). The water oxygen concentration was homogeneous across the sampling area, reaching about $7 \mathrm{mg} \mathrm{l}^{-1}$. Only Stn MAE 10 located in the estuary mouth had lower oxygen concentrations, between $5.6 \mathrm{mg} \mathrm{l}^{-1}$ at $3 \mathrm{~m}$ depth and $6.1 \mathrm{mg} \mathrm{l}^{-1}$ at $1 \mathrm{~m}$. The $\mathrm{pH}$ was also stable across the sampling area, with the exception of freshwater Stns MAE 6 and MAE 8 where it was slightly lower (Fig. 2).

\section{Trace metal levels and biogeochemistry}

Dissolved (Fig. 3) and particulate (Fig. 4) trace metal concentrations were plotted against salinity for all samples to identify the stations potentially subject to contamination (relative to the natural geochemical reactivity of trace metals with salinity). This approach was applied because fresh water and seawater were well mixed, as demonstrated by the $\mathrm{Si}$ distribution (Fig. 2).

For dissolved trace elements, conservative dilution distribution was observed for $\mathrm{Cu}, \mathrm{U}$ and $\mathrm{Zn}$ with dilution by marine waters. For $\mathrm{Zn}$ and $\mathrm{Cu}$, the negative slope resulted from main upstream riverine inputs and lower levels in seawater, whereas the positive slope for U results from the well known enrichment of this element in seawater compared to freshwater systems. $\mathrm{Pb}$ followed the trends of $\mathrm{Zn}$ and $\mathrm{Cu}$ up to $30 \mathrm{PSU}$. In the highest salinity stations, surprisingly high $\mathrm{Pb}$ concentrations were detected. For $\mathrm{Cd}$ and $\mathrm{Mn}$, the nonconservative trends reflect natural geochemical reactivity of the 2 elements (a result of desorption from the particulate fraction).

For particulate trace metals, 2 consecutive decreasing trends were observed for most elements across the salinity gradient (Fig. 4). In the range 0 to $30 \mathrm{PSU}$, all elements displayed a conservative profile relating to dilution with less concentrated marine waters. For $\mathrm{Cu}_{\text {, }}$ $\mathrm{Zn}$ and $\mathrm{Cd}$, the dilution trend was continuous over the salinity range 0 to $30 \mathrm{PSU}$, whereas for $\mathrm{Pb}$ and $\mathrm{Mn}$ a small increase occurred at low salinity (0 to 10 PSU) before manifesting significant dilution (10 to $30 \mathrm{PSU}$ ). At higher salinities (>30 PSU), pronounced drops in concentrations of the particulate trace metals were noticed. These can be attributed to the degree of modification of the original water masses. Indeed, up to salinity $30 \mathrm{PSU}$, samples collected within the estuarine 

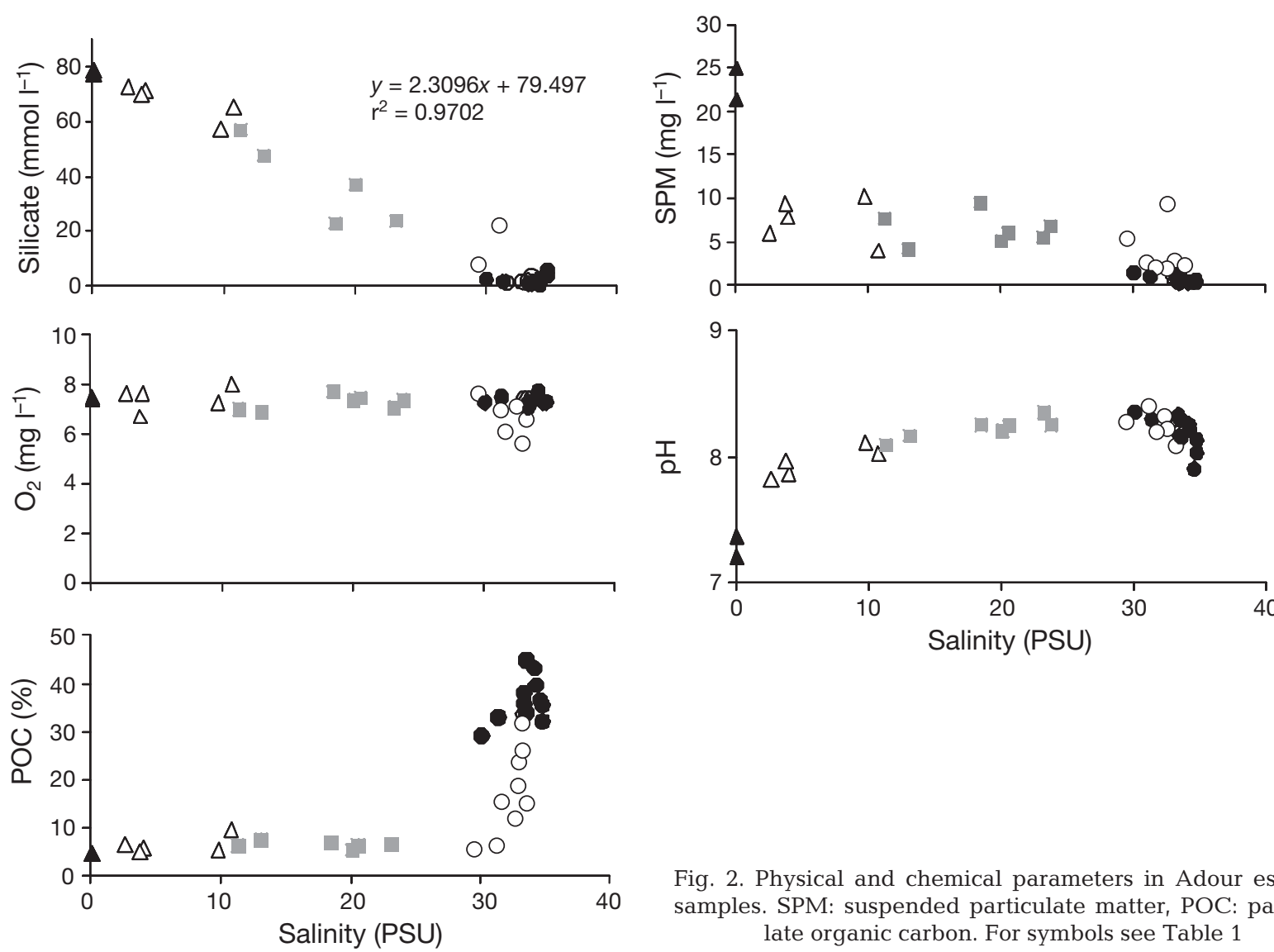

Fig. 2. Physical and chemical parameters in Adour estuary samples. SPM: suspended particulate matter, POC: particulate organic carbon. For symbols see Table 1

plume were expected to display dilution of riverine terrigenous material. At higher salinities (particularly $>34$ PSU) the turbidity plume signature was negligible; biogenic particles had significant levels of POC $(45 \%)$ (Fig. 2) and relatively low levels of trace elements compared to terrigenous material.

\section{Bacterial communities}

The electrophoregrams obtained for each sample (Fig. 5) constitute bacterial community fingerprints in which each peak (or T-RF for terminal restriction fragment) is considered as an OTU (operational taxonomic unit). The total numbers of T-RFs observed (representing more than $1 \%$ of total fluorescence) were 85 and 55 for the $5^{\prime}$ and $3^{\prime}$ ends, respectively. Twenty-six and 30 T-RFs for $5^{\prime}$ and $3^{\prime}$ ends, respectively, occurred exclusively in 1 sample. Depending on samples, the number of T-RFs varied from 7 to 32 when analysed by the $5^{\prime}$ end and from 3 to 20 when analysed by the $3^{\prime}$ end. Samples from seawater, mainly from Stn MAE 02, were the least diverse. Estuarine samples (MAE 05H 10 and MAE 03H 03) and samples from the mouth of the estuary (MAE 13H 12) were most diverse.

Principal component analysis (PCA) based on TRFLP profiles (Fig. 6) showed a good discrimination of the bacterial communities along the 2 main axes. Freshwater and estuarine bacterial communities were discriminated by axis $1(33.13 \%)$, and were mainly influenced by salinity (canonical correspondance analysis, CCA, data not shown) while bacterial communities from seawater were distributed mainly along axis $2(16.25 \%)$, and were influenced by depth (CCA, data not shown). Percentages of variation attributable to each axis indicate that the discrimination of estuarine bacterial communities was better than discrimination of communities from seawater.

Detailed examination of electrophoregrams shows that some T-RFs (Fig. 6B) may be considered as markers since they were present in specific bacterial communities. Three T-RFs (219, 232 and 277 bp) were characteristic of fresh water or low salinity waters (<11 PSU). In contrast, 2 T-RFs were detected exclusively in marine communities (202 and $325 \mathrm{bp}$ ). While T-RF 202 bp represented less than $5 \%$ of fluorescence, T-RF 325 bp was dominant in 2 bacterial communities (representing $41 \%$ and $52 \%$ in deep water Stns MAE 02-90 and MAE 01-45, respectively). Three T-RFs (182, 238 and $372 \mathrm{bp}$ ) were found exclusively in estuarine 

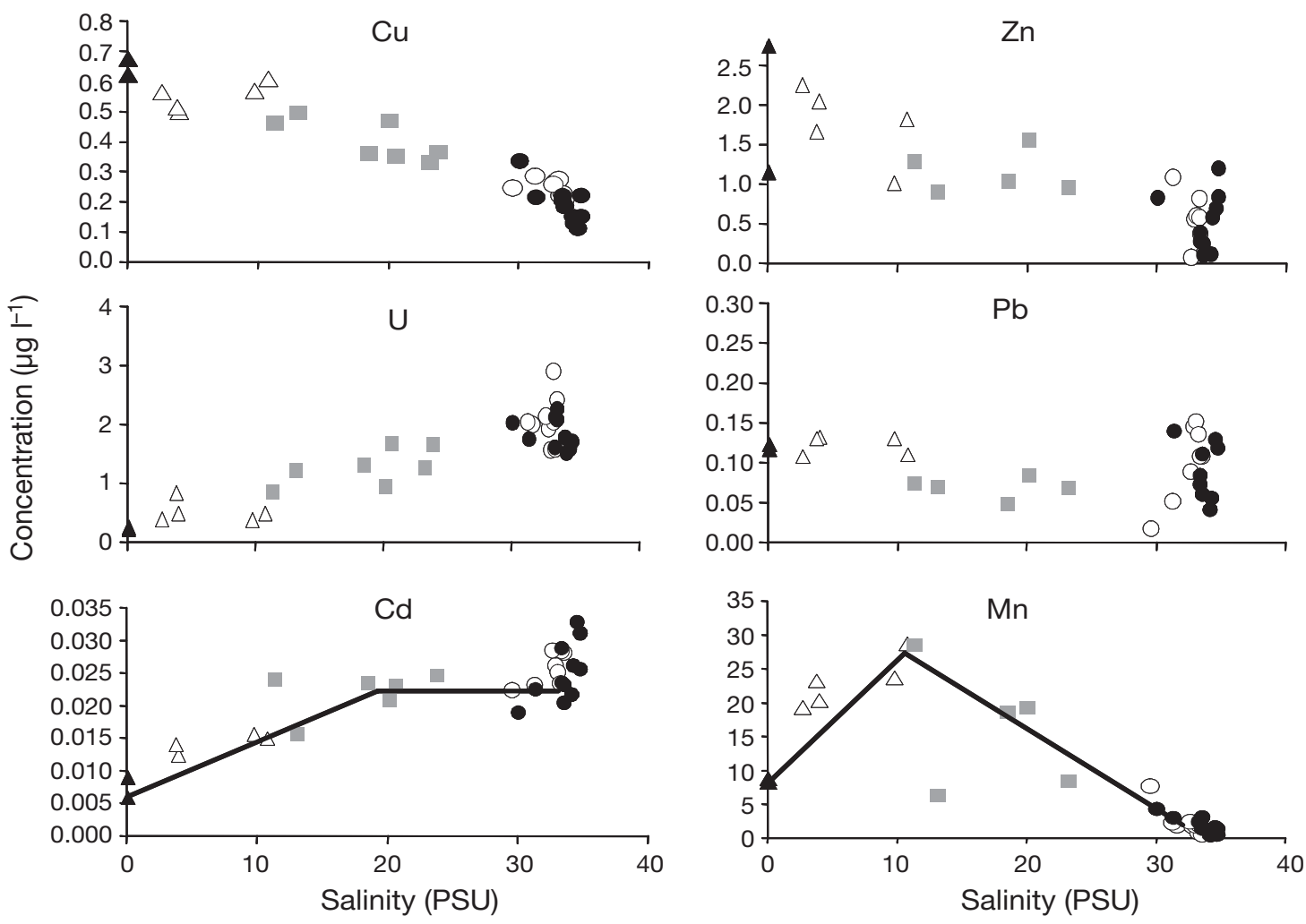

Fig. 3. Dissolved trace metal concentrations versus salinity. For symbols see Table 1
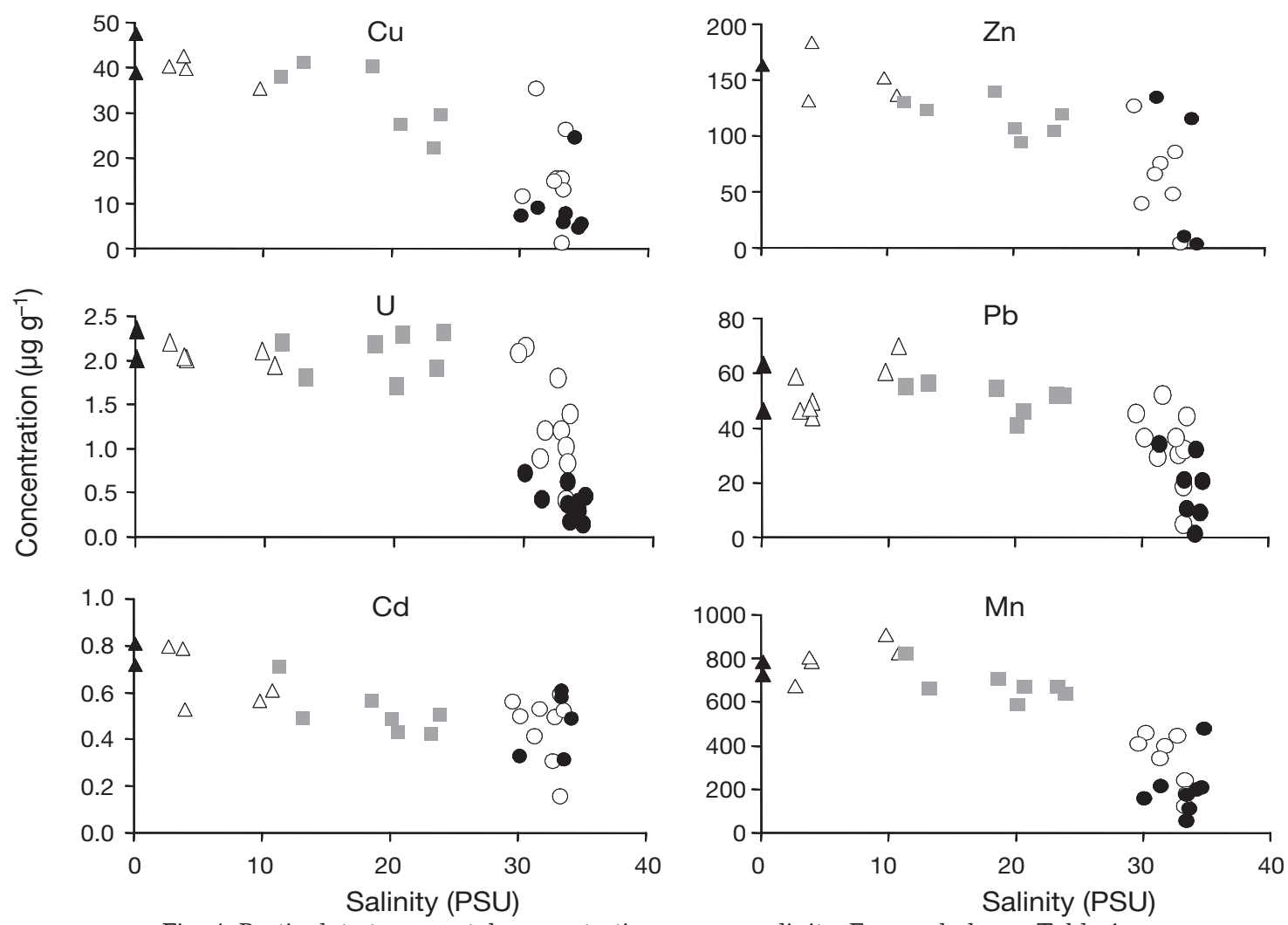

Fig. 4. Particulate trace metal concentrations versus salinity. For symbols see Table 1 


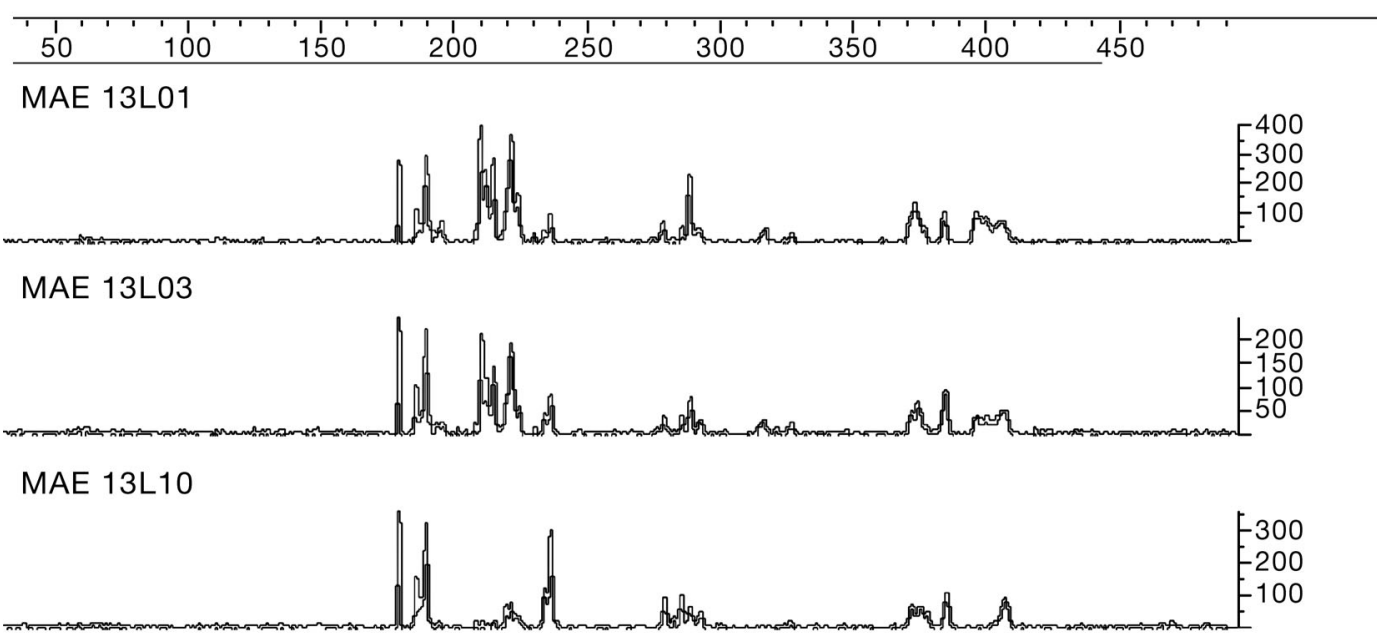

Fig. 5. T-RFLP profiles of samples obtained from different depths at low tide at Stn 13. The $x$-axis represents fragment length (bp) and the $y$-axis represents fluorescence. See Table 1 for sample code information

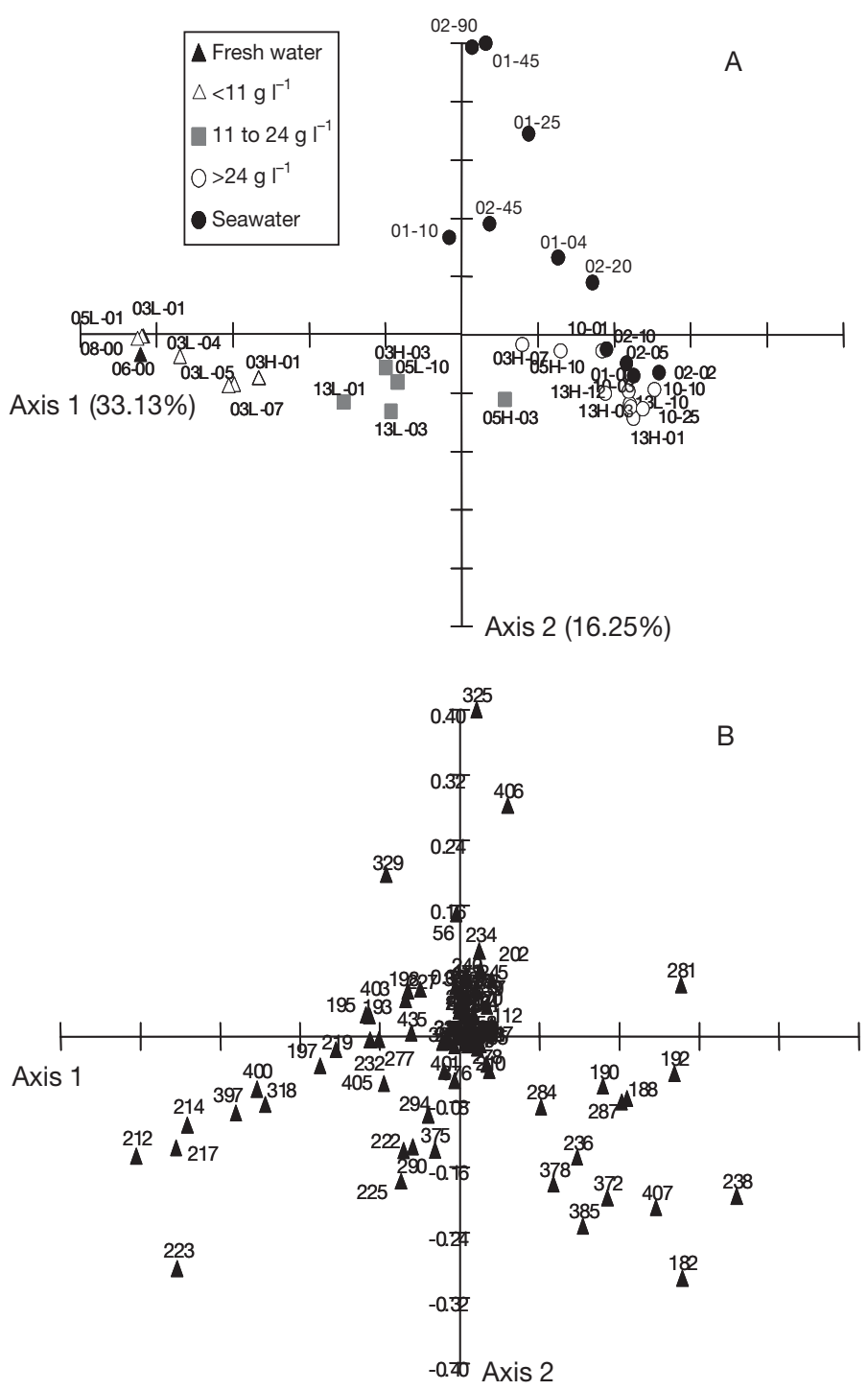

communities. T-RF 238 bp was the most abundant and represented between 10 and $22 \%$ of estuarine communities (salinities between 23 and 33 PSU, Fig. 7). Some T-RFs $(192,222,223,290$ and $375 \mathrm{bp})$ were found in all sampling stations. Their relative abundance (percentage of fluorescence) was generally low, with the exception of T-RFs 192 and 223 bp whose relative abundances varied with salinity. Interestingly, the relative abundances of other T-RFs varied with salinity (i.e. T-RFs 212, 214, 217 bp; Fig. 7). Their relative abundances may be characteristic of the mixing of waters in the estuary.

Putative identification of the main T-RFs showed that fresh water and low salinity waters (salinity < 13 PSU) were dominated by Betaproteobacteria and firmicutes (mainly Bacillales and Clostridiales) (T-RFs 219, 277, $232 \mathrm{bp}$ ), but population samples from higher salinities (up 29 PSU) were mainly Clostridiales (T-RFs 212, 214, 217, 318, 397, 400 bp). No Betaproteobacteria could be related to T-RFs recovered from these higher salinity waters.

T-RFs found in almost all samples were related mainly to Alpha- and Gammaproteobacteria and Actinobacteria (T-RFs 192, 222, 224, 290 bp). However, Alpha- and Gammaproteobacteria were more abundant in waters with salinities up to $10 \mathrm{PSU}$, whereas

Fig. 6. Comparison of bacterial communities in the Adour estuary. Principal Component Analysis (PCA) based on TRFLP (terminal restriction fragment length polymorphism) patterns (5' end) of PCR-amplified 16S rRNA genes digested by HaeIII. (A) PCA of samples (for symbols and sample codes see Table 1; sample codes in (A) are given without the prefix MAE). (B) PCA of variables, i.e. T-RFs derived from the PCA in (A) (numbers next to symbols in B correspond to the T-RF lengths in base pairs) 

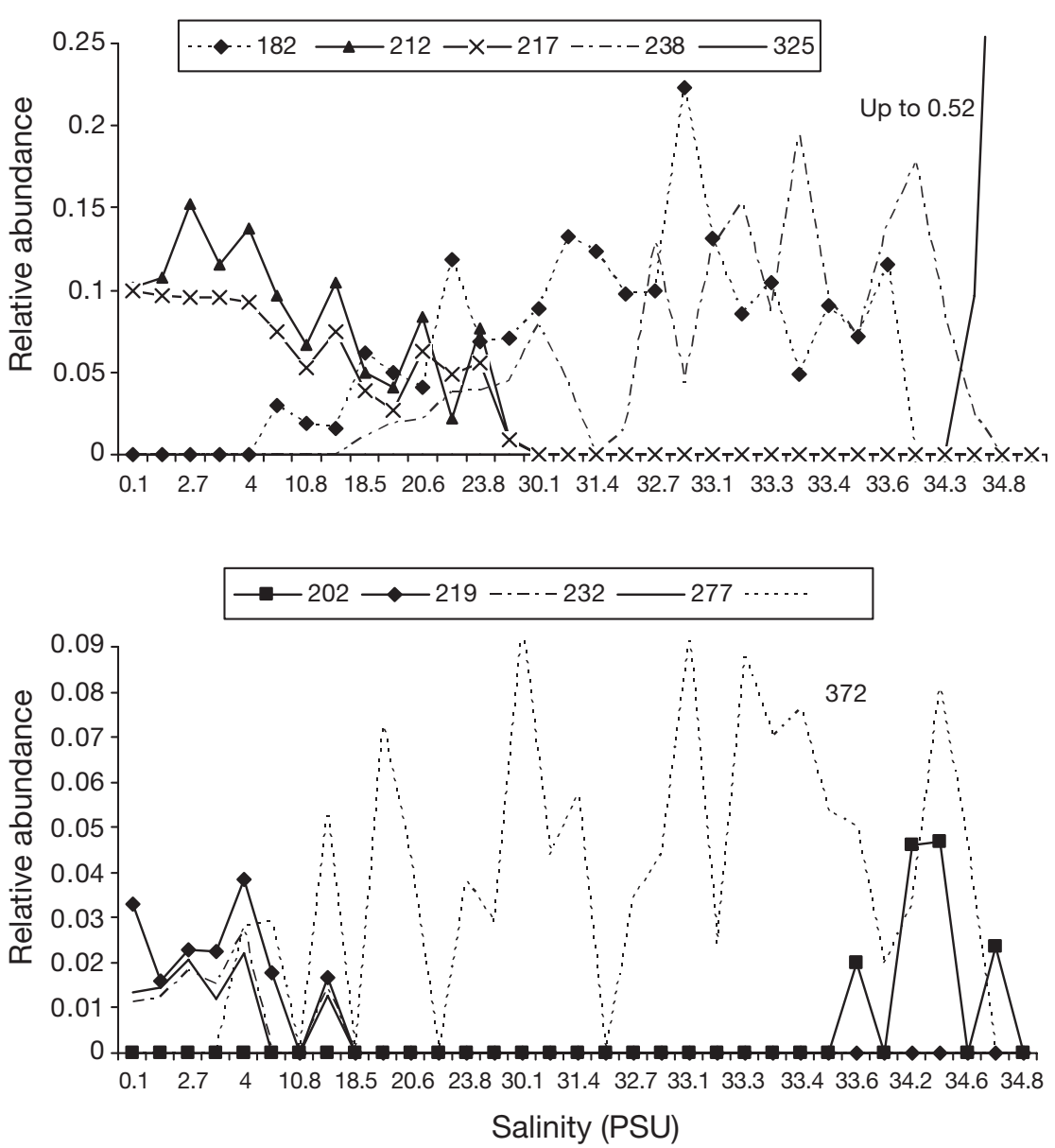

Fig. 7. Relative abundances of populations represented by the terminal restriction fragments (T-RFs) and having a characteristic distribution along the salinity gradient in the Adour estuary. Numbers in keys refer to T-RF lengths in base pairs

Actinobacteria were more important in waters with salinities <23 PSU. Estuarine T-RFs (salinity from 4 to 33 PSU) were related to Cyanobacteria, Planctomyces and Alphaproteobacteria (T-RFs 182, 188 bp). T-RFs obtained exclusively in waters of $>18$ PSU salinity were mostly firmicutes from Clostridiales, Haloanaerobiales, and Lactobacillales (T-RFs 190, 236, 238, 281, $287 \mathrm{bp})$. Seawater exclusive T-RFs mostly corresponded to the Cytophaga/Flexibacter group and to Gammaproteobacteria (T-RFs 202, 325, 385 bp).

\section{DISCUSSION}

The Adour macrotidal estuary has low turbidity waters due to low solid load transport (a few $\mathrm{mg}^{-1}$ ) under low flow conditions (Point 2004). It is affected by important anthropogenic modifications (such as an important harbour, dikes, important channelled waterways) that have increased current speed resulting in a low residence time (maximum $1 \mathrm{~d}$ ) for both water and particles (Maneux et al. 1999). The low residence time limits the formation of a high turbidity zone, as found in other major European macrotidal estuaries such as the Gironde (Kraepiel et al. 1997), the Seine (Chiffoleau et al. 1999) and the Scheldt (Zwolsman \& Van Eck 1999). The main objectives of this study were to determine (1) the distribution of bacterial communities within the Adour Estuary and (2) the influence of physico-chemical parameters such as salinity on bacterial diversity.

Trace metal distribution profiles across the salinity gradient were used to check for the occurrence of a residual contaminated plume that might affect biogeochemistry trends and thus the bacterial diversity. For most dissolved and particulate trace metals, distribution by salinity was represented by a pseudo dilution profile, as observed in other estuaries (Elbaz-Poulichet et al. 1996, Chiffoleau et al. 1999, Windom et al. 2000). The profiles of $\mathrm{Cd}$ and $\mathrm{Mn}$ in the dissolved phase are mostly linked to geochemical properties relating to particle desorption. Although high dissolved $\mathrm{Pb}$ concentrations occurred at higher salinities, the concentrations levels for all elements in the water samples were relatively low and similar to other reference uncontaminated river-estuarine systems (Point 2004, Point et al. 2006). Special attention to stations located within the estuary (samples found between KP 130 and 135) and potentially subject to anthropogenic sources (iron and steel industries, Point 2004) did not yield any evidence of a contamination signature. This is consistent with the limited contribution of the anthropogenic metal flux $(10 \%)$ discharged in the estuary relative to the upstream inputs that represent more than $90 \%$ of the total metal load during low river discharge and dry conditions (Point 2004). The high current speed measured in the channel (de Casamajor 1995) has the potential to maintain the local contamination plumes along the banks and leads to a low residence time of water and particles, limiting deposition and enhancing the direct transfer of particles to the coastal zone (Point 2004, Point et al. 2006). As a consequence, we found no evidence of an anthropogenic signature or influence of heavy metal contamination on bacterial diversity and abundance within the estuarine water plume sampled. Impacts of copper and 
zinc on bacterial communities in soil were demonstrated by Ellis et al. (2001); however, the concentrations of metals were 10- to 1000-fold higher than those found in this study. Moreover, the levels in the soil affect the physiological state of the microorganisms rather than their diversity (Ellis et al. 2003).

Bacterial communities from fresh water and estuarine waters were discriminated by PCA across the salinity gradient, revealing a well-defined estuarine bacterial community. When analysing the T-RFLP fingerprints, specific estuarine communities dominated by populations with relative abundances $>20 \%$ were observed. Similarly, the relative abundances of some dominant populations in fresh water dramatically decreased when salinity reached a critical threshold. In addition, some seawater populations disappeared in the estuary mouth even when salinity remained high. These results are not surprising since estuaries are ecosystems where variations in bacterial abundance and diversity can be rapid (del Giogio \& Bouvier 2002, Troussellier et al. 2002, Kirchman et al. 2005, Zhang et al. 2006).

Previous studies of estuarine bacterial communities have resulted in controversy. The composition of the estuarine bacterial populations in the Rhone estuary was considered to be a result of the mixing of river and marine bacterial communities (Troussellier et al. 2002), while in the Parker River estuary a specific estuarine community formed at intermediate salinity was found in summer and fall, but not in spring (Crump et al. 2004). Nevertheless, both these studies concluded that the region where largest community shift occurs is located between the river and the zone of about 1 PSU salinity. However, in our study major community composition changes occurred in higher salinities (4 to 10 PSU) between freshwater and estuarine regions, similar to the Choptank River estuary (del Giogio \& Bouvier 2002), and in salinities of 34 PSU between estuarine water and seawater. To explain the presence of a specific estuarine bacterial community, Crump et al. (2004) concluded that its stabilization depends on water residence time. In the Adour estuary, the residence time of waters is between a few hours and a few days during high to low discharge conditions ( $>100$ to $250 \mathrm{~m}^{3} \mathrm{~s}^{-1}$ ) (Maneux et al. 1999). The hydrological conditions observed through the study $\left(185 \mathrm{~m}^{3} \mathrm{~s}^{-1}\right)$ suggest that the residence time is on a day scale, comparable to the Rhone estuary and shorter than in the Parker River estuary, even in spring. Despite this, a well-defined estuarine bacterial community occurred, and therefore we assume that water residence time is not the main parameter determining the bacterial distribution in the Adour estuary.

Other studies point out the role of salinity and salinity changes in the establishment of bacterial communities in estuary waters (del Giorgio \& Bourvier 2002,
Kirchman et al. 2005, Zhang et al. 2006). However, they did not consider water residence time as a possible parameter influencing bacterial community composition. In the Adour estuary, salinity and halocline formation seem to be the main factors involved in the establishment of a specific bacterial community.

A comparison of the putatively identified communities of the Adour estuary with those from other studies is quite difficult. Studies with detailed bacterial identification include few samples, and most of these works discuss the difference between free living and particleattached bacteria (e.g. Crump et al. 1999, Hollibaugh et al. 2000). FISH techniques have been used to characterize the main bacterial groups in estuaries (del Giorgio \& Bourvier 2002, Kirchman et al. 2005, Zhang et al. 2006); this method allows analysis of many more samples. Our study was designed to observe bacterial community structure changes in relation to salinity, since the Adour estuary has low SPM concentrations and a limited anthropogenic impact. In fresh water and waters with salinities <13 PSU, we identified OTUs related to Betaproteobacteria and Gram positive bacteria. Actinobacteria, mainly detected in fresh water, were also found in estuarine and marine waters at lower relative abundances. Most previous studies found that freshwater communities are mainly composed of Betaproteobacteria (Zhang et al. 2006). Depending on the estuary (and hence the techniques used) freshwater communites also contain Gram positive bacteria (Columbia river estuary, Crump et al. 1999), Alphaproteobacteria and Actinobacteria (Weser estuary, Selje \& Simon 2003) and the CFB group (Cytophaga-Flavobacterium-Bacteroides, Parker River estuary, Crump et al. 2004). The relative abundances of Actinobacteria and Betaproteobacteria were strongly negatively correlated with salinity in the Delaware estuary (Kirchman et al. 2005).

In our study, marine waters were mainly colonized by Gram positive bacteria, CFB and Gammaproteobacteria. Previous studies reported marine (or high salinity) populations comprising mainly Alphaproteobacteria (Kirchman et al. 2005, Zhang et al. 2006), Cyanobacteria (mainly particle-attached, Crump et al. 1999) and CFB (Crump et al. 2004, Kirchman et al. 2005). Nevertheless, CFB is a very diverse group and has been detected through the estuarine gradient (Kirchman et al. 2005, Zhang et al. 2006), although the group tends to be most abundant at the marine end.

Our results using T-RFLP techniques are consistent with those of others studies that used more timeconsuming and higher resolution methodolgies for seawater and fresh water. However, cross comparisons of bacterial compositions in brackish waters are more difficult since information on sampling sites or analysis is lacking in most previous studies. In the Adour estu- 
ary, the exclusively estuarine communities were mainly Cyanobacteria, Planctomyces and Alphaproteobacteria. In this zone, populations related to Gamma- and Betaproteobacteria and Gram positive bacteria (present in fresh and marine waters) were also found.

In conclusion, we found a well-defined estuarine bacterial community in the Adour estuary. In the estuarine zone, a dilution of bacterial populations from fresh water and seawater were also observed. This suggests an adaptation of the estuarine community to fast changes (mostly salinity) occurring in the Adour estuarine waters. The trapping of bacteria in the ETM zone, as observed elsewhere, seems not to be a main factor in the establishment of this unique community.

Acknowledgements. This work was supported by the Aquitaine Region, DIREN Aquitaine, the Ecobag project and PNEC (Ifremer/INSU). We thank LEMAR (European Institute for Marine Studies, Plouzané) for the silicate analysis.

\section{LITERATURE CITED}

Chiffoleau JF, Auger D, Chartier E (1999) Fluxes of selected trace metals from the Seine estuary to the eastern English Channel during the period August 1994 to July 1995. Cont Shelf Res 19:2063-2082

Crump BC, Armbrust EV, Baross JA (1999) Phylogenetic analysis of particle-attached and free-living bacterial communities in the Columbia River, its estuary and the adjacent coastal ocean. Appl Environ Microbiol 65:3192-3204

Crump BC, Hopkinson CS, Sogin ML, Hobbie JE (2004) Microbial biogeography along an estuarine salinity gradient: combined influences of bacterial growth and residence time. Appl Microbiol Ecol 70:1494-1505

De Casamajor M. N. (1995) Mesures de salinité et temperature sur l'estuaire de l'Adour- Rapport interne IFREMER, St Pée sur Nivelle

del Giorgio PA, Bouvier TC (2002) Linking the physiological and phylogenetic successions in free-living bacterial communities along an estuarine salinity gradient Limnol Oceanogr 47:471-486

Elbatz Poulichet F, Garnier JM, Guan DM, Martin JM, Thomas AJ (1996) The conservative behaviour of trace metals $(\mathrm{Cd}, \mathrm{Cu}, \mathrm{Ni}$ and $\mathrm{Pb})$ and $\mathrm{As}$ in the surface plume of stratified estuaries: example of the Rhone River (France). Estuar Coast Shelf Sci 42:289-310

Ellis RJ, Neish B, Trett MW, Best JG, Weightman AJ, Morgan P, Fry JC (2001) Comparison of microbial and meiofaunal community analyses for determining impact of heavy metal contamination. J Microbiol Methods 45:171-185

Ellis RJ, Morgan P, Weightman AJ, Fry JC (2003) Cultivationdependent and independent approaches for determining bacterial diversity in heavy-metal-contaminated soil. Appl Environ Microbiol 69:3223-3230

Fourçans A, García De Oteyza T, Wieland A, Solé A and 8 others (2004) Characterization of functional bacterial groups in a hypersaline microbial mat community (Salins-
de-Giraud, Camargue, France). FEMS Microbiol Ecol 51: $55-70$

Hewson I, Fuhrman JA (2004) Richness and diversity of bacterioplankton along an estuarine gradient in Moreton Bay, Australia. Appl Environ Microbiol 70:3425-3433

Hollibaugh JT, Wong PS, Murrell MC (2000) Similarity of particle-associated and free-living bacterial communities in northern San Francisco Bay, California. Aquat Microb Ecol 21:103-114

Kirchman DL, Dittel AI, Malstrom RR, Conttrell MT (2005) Biogeography of major bacterial groups in the Delaware Estuary. Limnol Oceanogr 50:1697-1706

Kovach WL (1999) MVSP — a multivariate statistical package for Windows. Kovach Computing Services, Pentraeth

Kraepiel AML, Chiffoleau JF, Martin JM, Morel FMM (1997) Geochemistry of trace metals in the Gironde estuary. Geochim Cosmochim Acta 61:1421-1436

Lane DJ (1991) rRNA sequencing. In: Stachenbradt EGM (ed) Nucleic acid techniques in bacterial systematics. Wiley, Chichester, p 115-175

Maneux E, Dumas J, Clement O, Etcheber H, Charritton X, Etchart J, Veyssy E, Rimmelin P (1999) Assessment of suspended matter input into the oceans by small mountainous coastal rivers: the case of the Bay of Biscay. CR Acad Sci Ser IIA Earth Planetary Sci 329:413-420

Point D (2004) Spéciation et biogéochimie des éléments traces métalliques dans l'estuaire de l'Adour. PhD Thesis, University of Pau

Point D, Bareille G, Amouroux D, Etcheber H, Donard OFX (2007) Reactivity, interactions and transport of trace elements, organic carbon and particulate material in a mountain range river system (Adour River, France). J Environ Monit 9:157-167

Selje N, Simon M (2003) Composition and dynamics of particle-associated and free-living bacterial communities in the Weser estuary, Germany. Aquat Microb Ecol 30:221-237

Stoichev T, Amouroux D, Monperrus M, Point D, Tessier E, Barreille G, Donard OFX (2006) Mercury in surface waters of a macrotidal urban estuary (River Adour, south-west France). Chem Ecol 22:137-148

Strickland JDH, Parsons TR (1972) A practical handbook of sea water analysis. Bull Fish Res Board Can 167:1-310

Tréguer P, Le Corre P (1975) Manuel d'analyse des sels nutritifs dans l'eau de mer (utilisation de l'autoAnalyseur II Technicon). Laboratoire d'Océanographie chimique, Université de Bretagne Occidentale, Brest

Troussellier M, Schäfer H, Batailler N, Bernard L and 5 others (2002) Bacterial activity and genetic richness along an estuarine gradient (Rhone River plume, France). Aquat Microb Ecol 28:13-24

Weisburg WG, Barns SM, Pelletier DA, Lane DJ (1991) 16S ribosomal DNA amplification for phylogenetic study. J Bacteriol 173:697-703

Windom H, Smith R, Niencheski F, Alexander C (2000) Uranium in rivers and estuaries of globally diverse, smaller watersheds. Mar Chem 68:307-321

Zhang Y, Jiao N, Cottrell MT, Kirchman DL (2006) Contribution of major bacterial groups to bacterial biomass production along a salinity gradient in the South China Sea. Aquat Microb Ecol 43:233-241

Zwolsman JJG, van Eck GTM (1999) Geochemistry of major elements and trace metals in suspended matter of the Scheldt estuary, southwest Netherlands. Mar Chem 66: 91-111

Submitted: January 10, 2007; Accepted: July 10, 2007

Proofs received from author(s): September 11, 2007 